\title{
Systematic Studies on Anopheles galvaoi Causey, Deane \& Deane from the Subgenus Nysssorhynchus Blanchard (Diptera: Culicidae)
}

\author{
Maria Anice Mureb Sallum/ ${ }^{+}$, Eduardo Sterlino Bergo*, Daniel Corugedo Flores, \\ Oswaldo Paulo Forattini
}

\begin{abstract}
Núcleo de Pesquisas Taxonômica e Sistemática em Entomologia Médica, Departamento de Epidemiologia, Faculdade de Saúde Pública, Universidade de São Paulo, Avenida Dr. Arnaldo 715, 01246-904 São Paulo, Brasil *Superintendência de Controle de Endemias, Araraquara, SP, Brasil
\end{abstract}

Anopheles galvaoi, a member of the subgenus Nyssorhynchus, is redescribed based on morphological characters of the adults male and female, fourth-instar larva and pupa. Female, male genitalia, larval and pupal stages are illustrated. Data about medical importance, bionomics, and distribution are given based on literature records. Adult female of An. galvaoi can be easily misidentified as An. benarrochi Gabaldón and An. aquasalis Curry. A few characters are indicated for identifying female and immatures of An. galvaoi. Phylogenetic relationships among An. galvaoi and six other species of the Oswaldoi Subgroup are estimated using COII mtDNA and ITS2 rDNA gene sequences. Lectotype of An. galvaoi, an adult female from Rio Branco, State of Acre, is invalidated.

Key words: Culicidae - Anophelinae - Nyssorhynchus - Anopheles galvaoi - systematics

Anopheles galvaoi Causey, Deane \& Deane was described from specimens collected in Rio Branco, State of Acre, Brazil. Causey et al. (1943) considered the adult stage of An. galvaoi to be morphologically similar to that of An. aquasalis, however, similar to An. oswaldoi (Peryassú) based on characters of male genitalia. Later, Deane et al. (1946a) suggested that females of $A n$. aquasalis, An. benarrochi and An. galvaoi were morphologically similar and that there was no distinctive character to separate them. However, An. aquasalis could be separated from An. galvaoi and An. benarrochi based on its distribution range since the former was restricted to the coastal Region of Latin America (Deane et al. 1946a). Deane et al. (1946b) described the larval stage of $A n$. galvaoi which was demonstrated to be similar to those of An. goeldii Rozeboom \& Gabaldón (= An. nuneztovari Gabaldón), An. noroestensis Galvão \& Lane (=An. evansae Brèthes), and An. rangeli Gabaldón, Cova-Garcia \& Lopez. Forattini (1962) stated that female of An. galvaoi could be separated from that of An. aquasalis by having the wing basal dark spot as long as 0.5 length of humeral pale spot $\left(\mathrm{B}_{2}\right)$, and subbasal pale spot $\left(\mathrm{B}_{3}\right)$ shorter than subbasal dark spot. Gorham et al. (1967) suggested that An. benarrochi could be distinguished from An. galvaoi and An. aquasalis by the vein M (= vein 4) which is mainly dark-scaled in An. benarrochi, whereas it is all or mostly white-scaled in An. galvaoi and An. aquasalis. Also, the

The present paper received financial support from Fundação de Amparo à Pesquisa do Estado de São Paulo, grants no. 2001/ 03283-6 and no. 1999/10517-1.

${ }^{+}$Corresponding author. Fax: +55-11-3082.1898. E-mail: masallum@usp.br

Received 15 February 2002

Accepted 19 September 2002 distinction between An. galvaoi and An. aquasalis was possible based on relative length of the subbasal dark spot and subbasal white spot $\left(=\operatorname{spot} \mathrm{B}_{3}\right)$ of vein $\mathrm{C}$, subbasal white spot longer than subbasal dark spot in $A n$. galvaoi and shorter in An. aquasalis (Gorham et al. 1967). Faran (1980) reports that the character (relative length of basal dark spot and humeral pale spot) used by Forattini (1962) to separate An. aquasalis from An. galvaoi is not always true for An. aquasalis, and that the wing of $A n$. benarrochi is similar to that of An. galvaoi. Causey et al. (1943) included An. galvaoi in the "tarsimaculatus complex" (= An. oswaldoi) of the Nyssorhynchus subgenus. Similarly, Faran (1980) suggested that An. galvaoi belongs to the Oswaldoi Complex of the Oswaldoi Subgroup of the Albimanus Section of Nyssorhynchus. The Albimanus Section and also the Oswaldoi Group were demonstrated to be non-monophyletic by Sallum et al. (2000). Based on ultrastructure morphology of the egg, An. galvaoi is similar to An. konderi Galvão \& Damasceno, An. oswaldoi and $A n$. aquasalis (Sallum et al. 2002a). In contrast, $A n$. galvaoi and An. benarrochi can be easily distinguished by egg morphology (Lounibos et al. 1997, Sallum et al. 2002a).

An. galvaoi has been reported in several localities of Brazil and Paraguay. Since the separation of adult females from An. galvaoi, An. benarrochi and An. aquasalis is problematic, the distribution range of these species may be either overestimated or underestimated, especially because the focus of most studies was ecology and biology of vector species, and thus the species identification was mainly based on adult female and larva. The goals of the present study are to redescribe male and female adults, fourth-instar larva and pupal stage of An. galvaoi, and to compare adults and immatures of An. galvaoi with similar stages of morphologically similar species, and to estimate phylogenetic relationships among An. galvaoi and those morphologically similar species of the Oswaldoi Subgroup in the sense of Faran (1980). 


\section{MATERIALS AND METHODS}

Females of An. galvaoi were collected in Brazil, State of São Paulo, Bocaina, Jacaré-Pepira River, Route 255, km

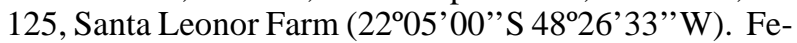
males were blood fed in order to raise progenies as reported by Sallum et al. (2002a). Larvae were reared to the adult stage, and fourth-instar larval and pupal exuviae with their respective adults were used to identify the species. Voucher specimens are deposited in the Entomological Collection at Faculdade de Saúde Pública, Universidade de São Paulo, Brazil (FSP-USP). Female and male specimens deposited in FSP-USP which were collected in other localities in the State of São Paulo, and two males with associated male genitalia on slides collected in the State of Minas Gerais and identified by Causey in 1952 were also used for comparison with specimens from Bocaina. Also, two paratypes, one male and one female deposited in IOC were used for description and comparisons.

DNA sequences for internal transcribed spacer 2(ITS2) nuclear gene rDNA for seven Nyssorhynchus taxa were downloaded from GenBank (Table I). ITS2 sequences consist of 352 base pairs (bp) (An. galvaoi) to $379 \mathrm{bp}$ (An. benarrochi). For cytochrome c oxidase subunit II (COII) mitochondrial gene, three sequences from a previous analysis using mtDNA (Sallum et al. 2002b) were included. Also, COII sequences (594 bp) for An. strodei Root, An. benarrochi, An. galvaoi, and An. oswaldoi were downloaded from GenBank (Table I). The taxa sampled for the present phylogenetic study, source and GenBank accession numbers for each sequence are listed in Table I.

Sequence alignment - Nucleotide sequences of COII and ITS2 were automatically aligned using the multiple alignment program ClustalX 1.8 (Thompson et al. 1997). The nucleotide alignment of COII generated 594 characters. No gaps were necessary to adjust COII sequence alignment. Alignment of ITS2 sequences was performed using default parameters in ClustalX 1.8 and adjusted by visual inspection using MacClade version 4.03 PPC (Maddison \& Maddison 2000). The alignment of ITS2 generated 417 positions. Twenty-one nucleotide positions (5\% of the positions in ITS2) were hypervariable and excluded from all the analyses. Coincidently, all the positions in this unalignable region were parsimony uninformative. Sequence data for COII and ITS2 were com- bined into a single data matrix using MacClade version 4.03 PPC (Maddison \& Maddison 2000).

Phylogenetic analysis - The data consist of 417 positions of nuclear ITS2 rDNA, and $594 \mathrm{bp}$ of COII mtDNA gene sequences. Parsimony (MP) and maximum likelihood (ML) analyses were performed only on combined dataset (i.e., COII + ITS2) using PAUP version 4.0b8 PPC (Swofford 2001). An. strodei was used as outgroup. Gaps for ITS2 sequences were treated as missing data in all the analyses. Twenty-one hypervariable positions of ITS2 were excluded from all analyses.

Parsimony analyses were implemented in PAUP version 4.0b8 PPC (Swofford 2001) using the heuristic search option with Tree Bisection-Reconnection (TBR) branchswapping and with parsimony-uninformative characters excluded; 10,000 random-taxon-additional replicate analyses were carried out for the unweighted analyses and 200 random-taxon-additional replicate analyses were carried out for the successive approximations weighted analyses. For the successive approximations weighted analyses, character weights were based on the maximum value of the rescaled consistency index and interactive rounds were continued until character weights stabilized (Farris 1969, Carpenter 1988). Bootstrapping (Felsenstein 1985) under parsimony utilized 1000 pseudoreplicates, with 100 random-taxon-additional replicates per pseudoreplicate; parsimony-uninformative characters were excluded.

To obtain an appropriate substitution model and model parameter values, as well as an optimal tree for branchswapping under ML, the single optimal tree obtained by parsimony analysis was evaluated using the computer program Modeltest 3.06 PPC (Posada \& Crandall 1998), which compares 14 basic substitution models. All 14 models were evaluated with and without rate heterogeneity. Rate heterogeneity was accommodated in three ways: using a gamma model, using an invariant sites model, and using a gamma plus invariant sites model (Swofford et al. 1996). Maximum likelihood analysis of combined data was performed under HKY (Hasegawa, Kishino \& Yano 1985) $+\Gamma$ (gamma-distributed rates) model of nucleotide evolution. Employing the adopted model and using the neighbor-joining tree generated for the combined dataset as the starting tree for branch-swapping, three interactive rounds of maximum-likelihood analyses were carried out. The most likely tree identified during each of the first two

TABLE I

Taxa, source and GenBank accession numbers for cytochrome C oxidase subunit II (COII) and internal transcribet spacer 2 (ITS-2) gene sequences used in this study

\begin{tabular}{|c|c|c|c|c|}
\hline \multirow[b]{2}{*}{ Taxon } & \multicolumn{4}{|c|}{ GenBank Accession Number / Reference } \\
\hline & COII & Reference & ITS2 & Reference \\
\hline An. (Nys.) aquasalis & AF417733 & Sallum et al. 2002b & U92324 & Danoff-Burg \& Conn (1997) ${ }^{a}$ \\
\hline An. (Nys.) benarrochi & U92379 & Danoff-Burg \& Conn (1997) ${ }^{a}$ & U92325 & Danoff-Burg \& Conn $(1997)^{a}$ \\
\hline An. (Nys.) galvaoi & U92339 & Danoff-Burg \& Conn (1977) ${ }^{a}$ & U92328 & Danoff-Burg \& Conn $(1997)^{a}$ \\
\hline An. (Nys.) nuneztovari & AF417736 & Sallum et al. (2002b) & U92351 & Danoff-Burg \& Conn (1997) ${ }^{a}$ \\
\hline An. (Nys.) oswaldoi & U92400 & Danoff-Burg \& Conn (1997) ${ }^{a}$ & U92344 & Danoff-Burg \& Conn (1997) ${ }^{a}$ \\
\hline An. (Nys.) rondoni & AF417737 & Sallum et al. (2002b) & U92330 & Danoff-Burg \& Conn $(1997)^{a}$ \\
\hline An. (Nys.) strodei & U92404 & Danoff-Burg \& Conn (1997) ${ }^{a}$ & U92354 & Danoff-Burg \& Conn $(1997)^{a}$ \\
\hline
\end{tabular}

$a$ : Danoff-Burg JA, Conn JE 1997. Character congruence in Anopheles mosquito phylogenetics (unpublished data). 
ML search rounds was used as the starting tree for the next search round, both for the calculation of updated parameter values and for the initiation of TBR branchswapping. Bootstrapping (Felsenstein 1985) under ML criterion utilized 100 pseudoreplicates, with 10 randomaddition starting tree per pseudoreplicates, and TBR branch-swapping. Hypervariable region was excluded from all analyses.

\section{RESULTS}

Morphology

Anopheles (Nyssorhynchus) galvaoi (Figs 1-3)

Causey et al. 1943: 293 (M*, F*, E*). Type locality: Rio Branco, State of Acre, Brazil. Causey et al. 1946: 27 (M*); Deane et al. 1946a, b: $12\left(\mathrm{~F}^{*}\right)$; 36, $42\left(\mathrm{~L}^{*}\right)$; Coher 1948 (1949): 88 (F); Belkin et al. 1965: 5 (lectotype des.); Faran
1980: 64 (M*, F* redescription); Marchon-Silva et al. 1996: 472 (paratype info.); Sallum et al. 2002a (SEM E*).

Female - Integument light brown with grayish pollinose. Head: interocular space with frontal tuft of long, pale yellow setae, and decumbent, curved, white, spatulate scales along ocular margin (Fig. 1A); vertex immediately posterior to frontal tuft with erect, white spatulate scales and a few long, pale yellow setae, remainder of vertex and occiput with erect black spatulate scales; postgena with tuft of black, spatulate scales and a few semierect, white, spatulate scales at junction of eyes; ocular setae dark brown to black; clypeus bare. Pedicel of antenna dark brown with decumbent, white spatulate scales on dorsal surface; flagellomere 1 with semierect, white scales on medial and lateral surfaces, sometimes a few white scales on ventral surface, and a patch of de-

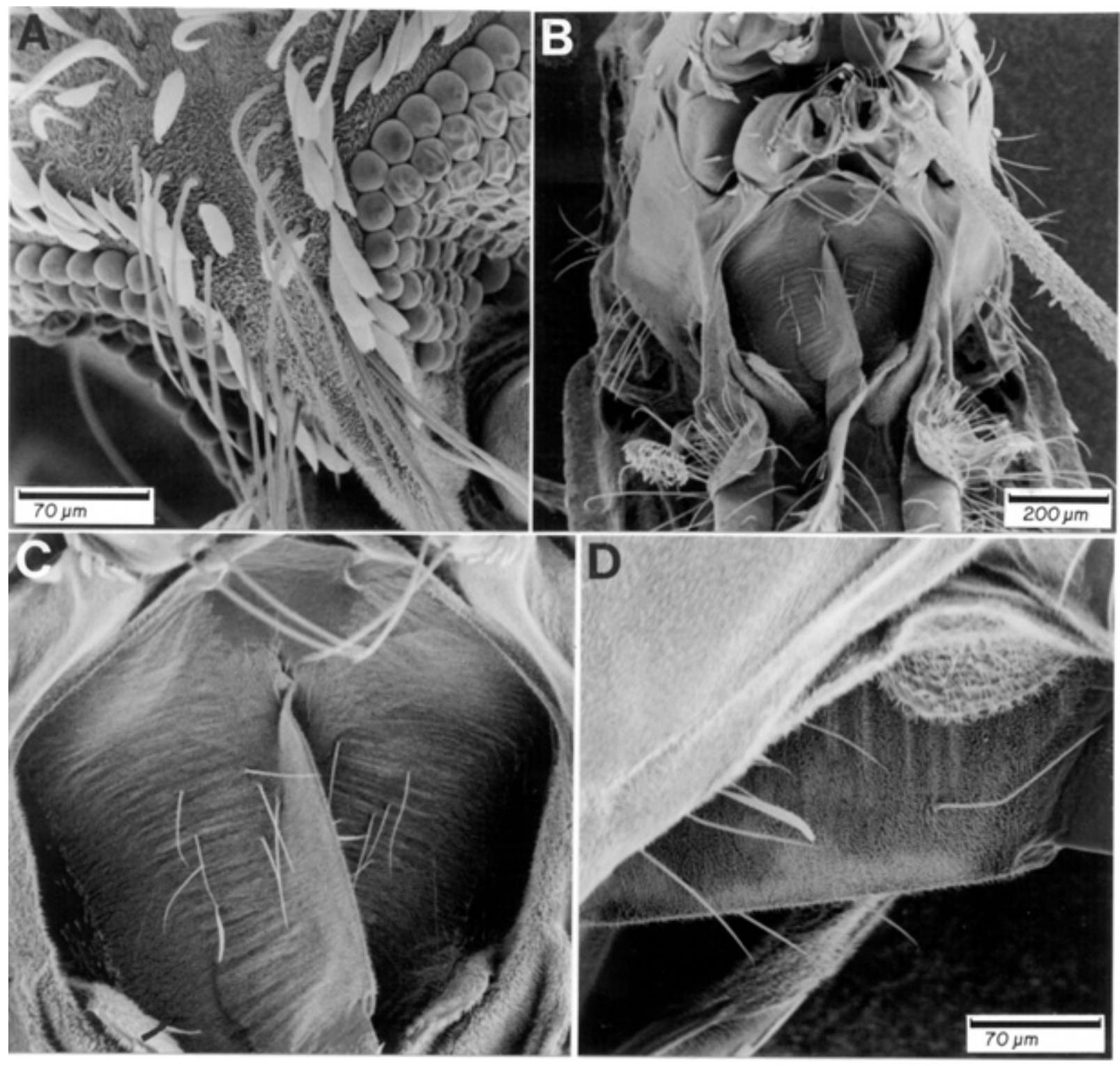

Fig. 1: Anopheles galvaoi. Adult female. A: interocular space; B: abdominal sternite I, ventral view; C: detail of abdominal sternite I, ventral view; D: abdominal sternite I, lateral view. 
cumbent, flat, broad white scales at base of dorsal surface. Proboscis dark-scaled; length $2.13-2.18 \mathrm{~mm}$ (mean $=2.15 \mathrm{~mm} \pm 0.039), 1.23-1.28$ length of forefemur $($ mean $=$ 1.26), $1.10-1.11$ length of maxillary palpus $(\mathrm{mean}=1.10)$ $(n=2)$. Maxillary palpomere 1 dark-scaled; palpomere 2 mostly dark-scaled with few white scales at apex of dorsal surface; palpomere 3 mostly dark-scaled with white scales at apex of dorsal surface; palpomere 4 mostly white-scaled with dark scales at base, sometimes a few dark scales present at lateral surface and apex; palpomere 5 mostly white-scaled with dark scales at base, scales erect on palpomeres 1 and 2, semierect and decumbent on dorsal surface, and erect on ventral surface of palpomere 3; length $1.93-1.98 \mathrm{~mm}($ mean $=1.96 \mathrm{~mm}), 0.91$ length of proboscis, length palpomere $2 /$ palpus length $=0.19-0.23$ (mean $=$ $0.21 \pm 0.029$ ); length palpomere $3 /$ palpus length $=0.37$ 0.40 (mean $=0.39 \pm 0.022)$; length palpomere $4 /$ palpus length $=0.16-0.19($ mean $=0.17+0.02)$; length palpomere $5 /$ palpus length $=0.13-0.14($ mean $=0.14 \pm 0.004)(n=2)$. Thorax: integument pruinose with darker area between dorsocentral area and lateral margin, at posterior edge of scutal fossa, and posteriorly on prescutellar area, extending posteriorly to median scutellar lobe; pale yellow, spatulate, decumbent scales on acrostichal and dorsocentral areas, scutal fossa, anteriorly on prescutellar area; supraalar and antealar areas with white, spatulate, decumbent scales; elongate, narrow, erect, white, spatulate scales along lateral margin of antealar area extending posteriorly onto supraalar area; scutum bare anteriorly between acrostichal and dorsocentral areas, posteriorly to scutal fossa, and posteriorly on prescutellar area; anterior promontory with erect piliform, white scales; lateral anterior end of dorsocentral area with erect, piliform scales; anterior lateral margin of scutum with erect, broad spatulate, white scales dorsally, black scales ventrally. Scutellum with few, spatulate, yellowish scales, posterior margin with long and short pale yellow setae. Mesopostnotum bare. Antepronotum with dark setae and a patch of spatulate scales, these scales pale yellow to white dorsally, dark brown ventrally on upper area, remainder of antepronotum without scales, with scattered pale yellow setae. Pleura with small patches of pale yellow, spatulate scales on upper mesokatepisternum, posterior border of middle mesokatepisternum and prealar knob; dark brown setae on upper proepisternum, pale yellow setae on upper mesokatepisternum, middle posterior border of mesokatepisternum, prealar knob, upper mesepimeron and prespiracular area. Wing: length $3.17-3.32 \mathrm{~mm}$ (mean = $3.25 \mathrm{~mm} \pm 0.07)(n=3)$; wing spots measurements in Table II; veins dark-scaled with spots of pale yellow scales as follows: costa always with basal pale, pre-humeral dark, humeral pale, humeral dark, presector pale, subcostal pale, preapical dark, preapical pale and apical dark spots; sector pale and proximal sector dark present in 50\% of wings examined; presector dark, accessory sector pale and distal sector dark frequently present, rarely absent; remigium white-scaled; vein $\mathrm{R}$ base pale about 0.7 distance to sector pale spot; $\mathrm{R}_{1}$ with accessory sector pale, subcostal pale, preapical pale spots; $R_{2}$ mostly dark-scaled with preapical pale spot and a pale spot at proximal end at furcation with vein $R_{3} ; R_{S}$ with a patch of pale scale at junction of $R_{4+5}$, and a few pale scales on basal $0.5 ; R_{2+3}$ with a patch of pale scales along middle region and a few dark scales at apex just before furcation of $R_{2}$ and $R_{3}$; $\mathrm{R}_{4+5}$ mostly pale-scaled, with small patch of dark scales at proximal 0.2 and distal end; vein $\mathrm{M}$ variable, mostly dark-scaled, or with pale scales at basal $0.3-0.5$, or mostly pale-scaled with dark spot at middle region and at distal end at furcation of $\mathrm{M}_{1+2}$ and $\mathrm{M}_{3+4}$; CuA mostly palescaled with small dark spot at distal 0.2 before furcation of $\mathrm{CuA}_{1}$ and $\mathrm{CuA}_{2} ; \mathrm{CuA}_{1}$ mostly pale-scaled with 2 separate dark spots at basal 0.5 and a small dark spot at distal end; pale fringe spots at apices of veins $\mathrm{R}_{2}, \mathrm{R}_{4+5}, \mathrm{M}_{1+2}$, $\mathrm{M}_{3+4}, \mathrm{CuA}_{1}, \mathrm{CuA}_{2}$ and $1 \mathrm{~A}$. Halter: scabellum and pedicel with pale integument; capitellum dark-scaled with patch of white scales at base. Legs: anterior surface of forecoxa

TABLE II

Wing spot measurements (in mm) for male and female of Anopheles galvaoi

\begin{tabular}{|c|c|c|c|c|c|c|c|c|}
\hline \multirow[b]{2}{*}{ Spot } & \multicolumn{4}{|c|}{ Female } & \multicolumn{4}{|c|}{ Male } \\
\hline & Range & Mean & S D & $\mathrm{N}$ & Range & Mean & S D & $\mathrm{N}$ \\
\hline Basal pale & $0,17-0,21$ & 0,19 & 0,02 & 3 & $0,13-0,19$ & 0,17 & 0,02 & 7 \\
\hline Prehumeral dark & $0,05-0,07$ & 0,05 & 0,01 & 3 & $0,02-0,09$ & 0,05 & 0,02 & 7 \\
\hline Humeral pale & $0,21-0,24$ & 0,22 & 0,01 & 3 & $0,16-0,28$ & 0,23 & 0,04 & 7 \\
\hline Humeral dark & $0,08-0,11$ & 0,09 & 0,01 & 3 & $0,04-0,19$ & 0,09 & 0,05 & 7 \\
\hline Presector pale & $0,12-0,13$ & 0,12 & 0,01 & 3 & $0,07-0,16$ & 0,13 & 0,03 & 7 \\
\hline Presector dark & $0,34-0,51$ & 0,4 & 0,09 & 3 & $0,35-0,56$ & 0,45 & 0,09 & 6 \\
\hline Sector pale & $0,08-0,09$ & 0,08 & 0,003 & 3 & $0,04-0,06$ & 0,05 & 0,01 & 3 \\
\hline Proximal setor dark & $0,06-0,06$ & 0,06 & 0,004 & 3 & $0,07-0,15$ & 0,12 & 0,04 & 3 \\
\hline Accessory setor pale & $0,08-0,10$ & 0,09 & 0,01 & 3 & $0,13-0,16$ & 0,14 & 0,02 & 6 \\
\hline Distal setor dark & $0,71-0,73$ & 0,72 & 0,01 & 3 & $0,50-0,61$ & 0,56 & 0,04 & 6 \\
\hline Subcostal pale & $0,21-0,25$ & 0,24 & 0,02 & 3 & $0,20-0,34$ & 0,3 & 0,05 & 7 \\
\hline Preapical dark & $0,68-0,80$ & 0,75 & 0,06 & 3 & $0,46-0,56$ & 0,53 & 0,04 & 7 \\
\hline Preapical pale & $0,16-0,25$ & 0,2 & 0,05 & 3 & $0,15-0,25$ & 0,2 & 0,03 & 7 \\
\hline Apical dark & $0,05-0,09$ & 0,07 & 0,02 & 3 & $0,07-0,11$ & 0,09 & 0,01 & 7 \\
\hline Total length & $3,17-3,32$ & 3,25 & 0,07 & 3 & $2,77-3,14$ & 3,03 & 0,14 & 7 \\
\hline
\end{tabular}

SD: standard deviation; $\mathrm{N}$ : number of specimens analyzed. 
with a patch of spatulate scales distally, these scales white laterally and dark medially, and a few white, spatulate scales proximally, posterior surface of forecoxa with a patch of ventrally directed, black, spatulate scales, these scales white at posterolateral side; outer surface of midcoxa with patches of white, spatulate scales, proximal patch with semierect scales, posterior surface with patch of white, spatulate scales at apex, anterior surface with patch of white scales at apex; anterior surface of hindcoxa with small patch of white, spatulate scales, posterior surface with few scales at apex, small patch of white, spatulate scales at base of lateral surface. Fore-, mid- and hindtrochanters pale and dark-scaled. Foretarsomeres 1 3 with apical, pale yellow to white scales; foretarsomeres 4,5 totally dark-scaled, sometimes tarsomere 5 pale-scaled at about apical 0.5 ; midtarsomere 2 with an apical ring of pale yellow to white scales, midtarsomere 3 with a few apical pale yellow to white scales, segment 4 entirely darkscaled, segment 5 with pale yellow scales at about apical 0.5 ; hindtarsomere 2 dark-scaled in basal $0.48-0.52$; hindtarsomere 5 dark-scaled in about basal $0.56-0.64$; remainder of hindtarsomeres 2 and 5 and tarsomeres 3 and 4 white-scaled. Abdomen: integument light to darkbrown; terga II - VII covered with goldenish, narrow, curved scales, mostly scales disposed in a subtriangular pattern on segment II - V, segments VI - VII more equally covered with scales; dark caudolateral scales tufts large, present on tergites II - VII. Sternite I with few short, pale yellow submedian setae (Fig. 1B-D), and a few white, broad, spatulate, submedian scales.

Male (Fig. 2) - Similar to female except for sexual differences. Maxillary palpus pale and dark-scaled, scales semierect on basal 0.5 of palpomere 2 , decumbent on remaining of palpomere 2 and palpomeres 3 - 5; medial surface of palpomeres without scales, palpomere 3 with long, strong, dark brown setae at apex of medial surface, palpomere 4 with long, dark brown setae along dorsal and ventral margins of medial surface; palpomere 2 with sparse, pale scales at basal 0.5 , white scales mostly on dorsal surface, white band at junction of palpomere 3; palpomere 3 white-scaled at base and at apex; palpomere 4 mostly white-scaled with subbasal and subapical bands of dark scales extending from dorsal to ventral surface, ventral surface dark-scaled; palpomere 5 mostly white-scaled on dorsal surface with basal band of dark scales, lateral and ventral surfaces mostly dark-scaled. Male genitalia: in general similar to that described by Faran (1980) who should be seen for details.

Pupa (Fig. 2) - Position and development of setae as figured; range and modal number of branches in Table III. All measurements were made in 9 to 10 specimens unless otherwise indicated. Cephalothorax: integument weakly pigmented; leg cases darker; trumpet angusticorn with meatal cleft; pinna moderately pigmented; meatal cleft basally pointed. Abdomen: length $2.18-3.02 \mathrm{~mm}$ (mean $=$ $2.63 \mathrm{~mm} \pm 0.24$ ); seta 2 - I with 3 - 7 branches; 3 - I single as long as 2-I; 4-I with 2 - 7 branches; 5, 6-I single, long; 7-I with 2 - 5 branches, as long as or shorter than 6-I; 9-I single as long as 7-I; 0-II - VII moderately developed, 0-II with 2 - 6 branches, 0 -III with 3 - 7 branches, 0 - IV with 2 - 5 branches, 0-V - VII often triple; 1-II, III well developed, with 3 - 9 and 2 - 8 branches, respectively, 1-IV- VII always single, strong, long, extending beyond the following segment; 3-IV with 2 - 5 branches, extending beyond caudal margin of segment, $3-\mathrm{V}$ often double, extending slightly beyond caudal margin of segment; 5-III with $2-10$ branches, slightly shorter than length of following segment, 5-IV with 3 - 5 branches, 5-V-VII normally single; 6II most often single ( 1 - 4 branches), 1 - 1.56 length of 7-II $($ mean $=1.32 \pm 0.25)(n=6), 6$-III single to triple, 6-IV-VII single; 7-II with 2 - 4 branches, 7-III, V normally double, 7IV often triple, 7-VI, VII single; 8-III with 2 - 4 branches, 8IV- VII normally double; 9-II minute, unpigmented, 9-III short, stout, $1.10-1.86($ mean $=1.44 \pm 0.255)$ length of 9-II, 9-IV tick, $1.23-3.36$ (mean $=2.04 \pm 0.601)$ length of 9-III, dark, 9-V strong, $1.50-2.75($ mean $=2.06 \pm 0.425)$ length of 9-IV, 9-VI strong, weakly curved, $1.09-1.50$ (mean $=1.27 \pm$ 0.143 ) length of 9-V, 9-VII strong, weakly curved, sharply pointed, $0.96-1.89($ mean $=1.27 \pm 0.259)$ length of 9-VI, 9VIII straight, $0.92-1.26$ (mean $=1.07 \pm 0.097)$ length of 9VII, 9-II - IV less than 0.10 length of segment, 9-VI - VIII less than 0.40 length of segment; 10 -III normally triple (1 3 branches), 10-IV, V always single, long; 10-VI present in 4 out of 10 specimens examined for this study; one extra seta, possible seta 12 -VI present in 6 out of 10 specimens examined, this seta is uncommon within the genus Anopheles; 4-VIII with 1 - 4 branches. Genital lobe: tick at base, with sides sloping toward apex, apex with mamiliform protuberance. Paddle: obovate, $1.14-1.34$ (mean $=1.24 \pm$ $0.055)$ more long than wide, length $0.64-0.78 \mathrm{~mm}$ (mean $=$ $0.73 \mathrm{~mm} \pm 0.04)$, width $0.50-0.64 \mathrm{~mm}($ mean $=0.59 \mathrm{~mm} \pm$ $0.045)$; refractile index $0.66-0.76($ mean $=0.70 \pm 0.03)$, outer margin distal of buttress with very fine, minute spicules, extending around apex and becoming sparse along caudal 0.5 of inner margin; seta 1-P stronger than 2-P, 2-P single or double.

Fourth-instar larva (Fig. 3) - Position and development of setae as figured; range and modal number of branches in Table IV. Measurements were made in 8 or 9 specimens unless otherwise indicated. Head: length 0.60 $-0.67 \mathrm{~mm}($ mean $=0.63 \mathrm{~mm} \pm 0.23)$; width $=0.60-0.64 \mathrm{~mm}$ $($ mean $=0.61 \mathrm{~mm} \pm 0.17)(n=6)$. Integument weakly pigmented with dark spots on posterior region of dorsal apotome and lateralia; mental plate strongly sclerotized, blackish; median tooth moderately broad, about twice as wide as adjacent tooth, tapered to point, blunt at apex. Seta 2-C single with sparse aciculae on 0.5 distal, 1.03 1.58 length of $3-\mathrm{C}($ mean $=1.32 \pm 0.168)$, seta $2-\mathrm{C}$ close to mate of opposite side, distance between bases 2.40 4.50 (mean $=3.45 \pm 0.75)$ width base of single seta; $3-\mathrm{C}$ single, weakly aciculate, $0.63-0.98$ length of $2-\mathrm{C}($ mean $=$ $0.77 \pm 0.10)$; clypeal index $1.83-2.92($ mean $=2.36 \pm 0.34)$ (distance between bases of 2-C and 3-C on one side / distance between the bases of 2-C). Seta 4-C with 2 - 5 branches, short, extending half way to anterior margin of head; 8-C with 3 - 7 branches; 9-C with 4 - 10 branches; $10,12-\mathrm{C}$ with 2 - 4 and 2 - 6 branches, respectively; $13-\mathrm{C}$ with 4 - 6 branches. Collar dark brown, moderately wide dorsolaterally. Antenna: length $0.28-0.33 \mathrm{~mm}$ (mean = $0.30 \mathrm{~mm} \pm 0.016)$ enlarged toward base, $5.80-6.71($ mean $=$ $6.31 \pm 0.308)$ more long than wide; with long and thin spicules on mesal margin, spicules shorter and fewer on 

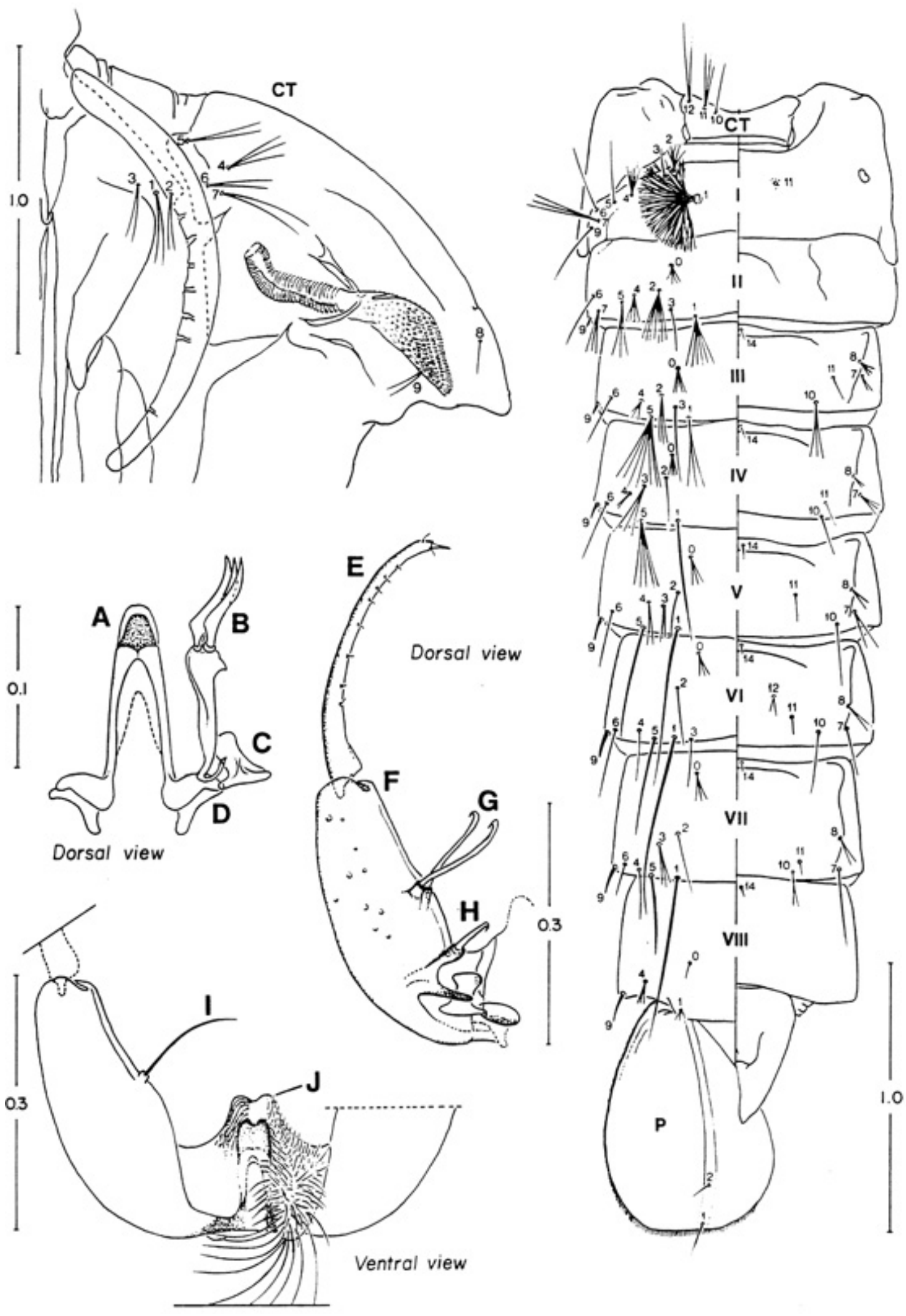

Fig. 2: Anopheles galvaoi. Male genitalia and pupa. A: aedeagus; B: dorsal claspette; C: gonocoxal apodeme; D; parameter; E: gonostylus; F: gonocoxite; G: accessory seta; H: parabasal seta; I: internal seta; J: ventral claspette; CT: cephalothorax; P: paddle; I - IX: abdominal segments, left side dorsal, right side ventral; scales in $\mathrm{mm}$. 


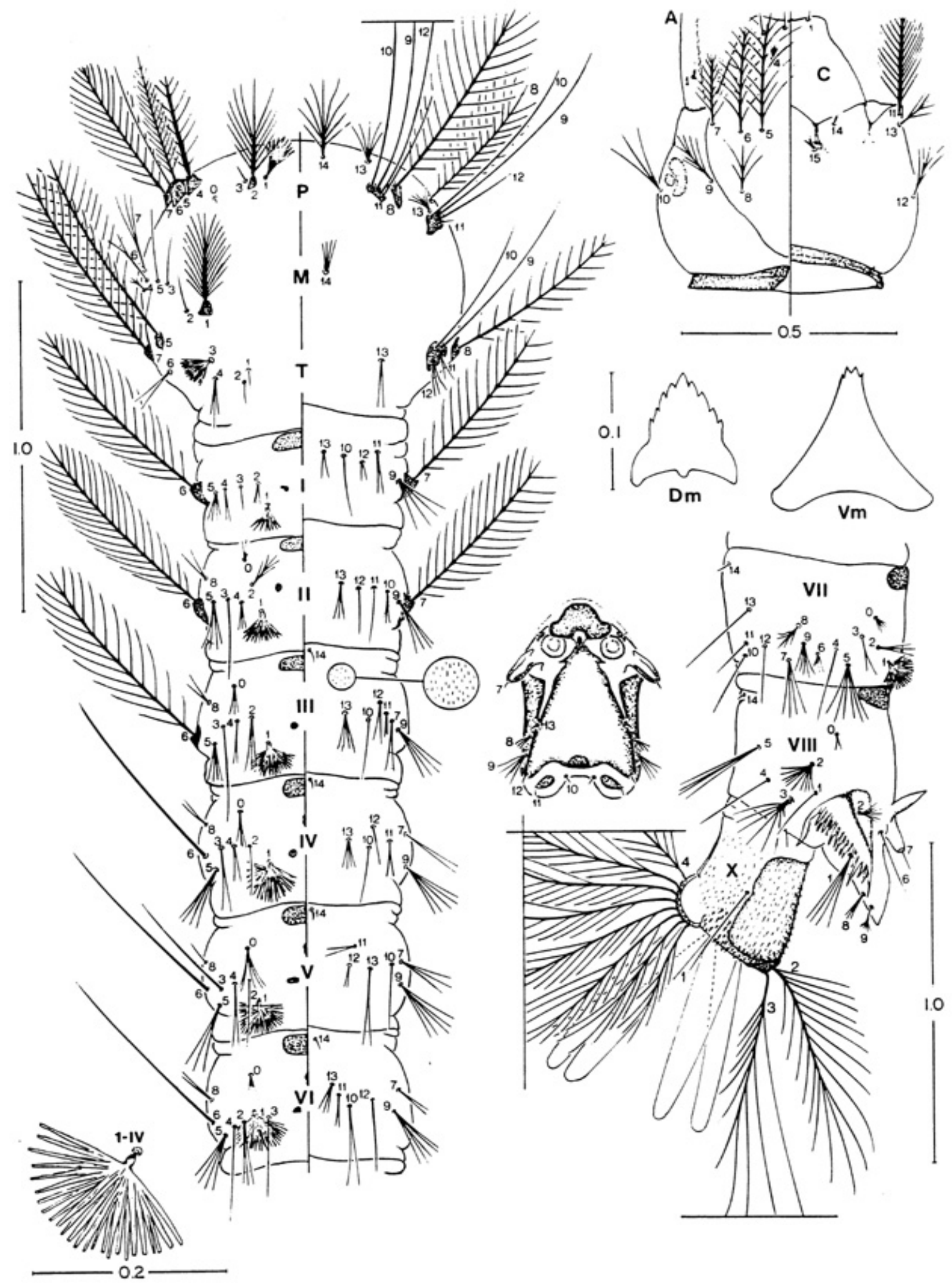

Fig. 3: Anopheles galvaoi. Larva. A: antenna; C: head; Dm: dorsomentum; P: prothorax; M: mesothorax; T: metathorax; Vm: ventromentum; I - VIII: abdominal segments; X: anal lobe; scales in mm. 
dorsal and ventral surfaces; seta 1-A with 6 - 12 branches, about as long as width of antenna at point of insertion, $0.13-0.26$ (mean $=0.16 \pm 0.045$ ) distance from base; seta 2A with minute spicules on mesal margin. Thorax: seta 1, 2-P not sharing a common tubercle; 1-P palmate, with 8 14 moderately narrow, lanceolate leaflets; leaflets truncate at apex, 2-P with $11-19$ branches; 14-P with 7 - 12 branches, large, branches arising from a short shaft, median branches longer than lateral branches, extending beyond anterior margin of thorax; 1-M strongly plumose, 21 - 34 branches; 2 -T long, extending beyond caudal margin of thorax; 3-T palmate, with 7 - 14 moderately long, narrow leaflets. Abdomen: integument with minute spicules on ventral surface of segments II - VIII; seta 0-II VII moderately large, often with 5 branches; 1-I - VII palmate, 1-I with 8 - 15 narrow leaflets, 1-II - VII with dark, moderately narrow, truncate leaflets; 2-II with $3-7$ branches, strongly developed, large, 2-III with 3 - 6 branches, stronger than 2-II; 2-IV single, 2-V long, single or double; 5-I with 3 - 5 branches, inserted about its length from lateral margin of abdomen; 5-II with 6 - 10 branches; 11-I with 3 - 5 branches, large; 13-I, II, III with 5 - 9, 8 - 12, 7 - 12 branches, respectively, 13-IV with 4 - 6 branches, large, subequal to $2-\mathrm{V}$, extending beyond caudal margin of segment, 13-VI with 6 - 12 branches, moderately developed. Pecten with 3 - 5 long, 12 - 16 short spines, long spines $1.64-2.32($ mean $=1.88 \pm 0.22)$ length of short spines; lateral arm of median plate of spiracular apparatus short, direct dorsolaterally; setae 8, 9-S with $1-6$ and $3-6$ branches, respectively. Segment X: most of segment covered with fine spicules, spicules stronger on posterior margin; seta 1-X as long as length of saddle, inserted outside saddle; anal gills longer than saddle.

Distribution - Since distinction among An. galvaoi, An. benarrochi and An. aquasalis by adult female is problematic, perhaps these three taxa have been largely misidentified throughout their distribution range. Conse- quently, it would be important to collect and raise immatures to adult in order to have male and female with associated larval and pupal exuviae for accurate identification and to have a better understanding of the distribution of those species. Distribution data for An. galvaoi listed in the present study are from literature records, and thus may be either underestimated or overestimated.

An. galvaoi is known from Brazil and Paraguay. In Brazil it was found in the States of Acre, Amazonas, Rondônia, Mato Grosso, Pará and São Paulo (Faran 1980). Literature records also report An. galvaoi in the States of Rio de Janeiro, Goiás and Paraná, however, these records were questioned by Faran (1980). More recently, An. galvaoi was found in the Ribeira Valley, southeast of the State of São Paulo (Dutra et al. 1996), in the vicinities of the States of São Paulo and Paraná, more specifically, in the Paranapanema River basin (Tubaki et al. 1999), in the Itaipu Dam area, west of the State of Paraná near border of Brazil and Paraguay (Guimarães et al. 1997), north of the State of Paraná (Lopes \& Lozovei 1995), in the State of Maranhão in a malaria endemic area (Xavier \& Rebêlo 1999, Oliveira-Pereira \& Rebêlo 2000), in the State of Amazonas (Lourenço-de-Oliveira \& Luz 1996), and in the States of Rondônia and Amapá (Tadei et al. 1998). Finally, An. galvaoi occurs in the State of Minas Gerais. This new record in Brazil is based on two adult male which were collected and identified by Causey in 1952 and are deposited in FSP-USP Entomological Collection.

Medical importance - Not known but Tadei et al. (1998) found females of An. galvaoi positive for Plasmodium vivax in an immunoenzymatic test using monoclonal antibodies against circumsporozoites.

Bionomics - It is important to have in mind that literature records on biology of An. galvaoi could refer to either one of those morphologically similar species that could be easily misidentified with An. galvaoi or perhaps to several mixed species. In the present work, we summa-

TABLE III

Number, range (mode), of branches for setae of the pupa Anopheles galvaoi ${ }^{a}$

\begin{tabular}{|c|c|c|c|c|c|c|c|c|c|c|c|}
\hline \multicolumn{3}{|c|}{ Seta Cephalothorax } & \multicolumn{8}{|c|}{ Abdominal segments } & \multirow{2}{*}{$\begin{array}{c}\text { Paddle } \\
\text { P }\end{array}$} \\
\hline no. & $\mathrm{CT}$ & I & II & III & IV & $\mathrm{V}$ & VI & VII & VIII & IX & \\
\hline 0 & - & - & $2-6(4)$ & $3-7(5)$ & $2-5(4)$ & $2-5(3)$ & $2-4(3)$ & $2-5(3)$ & $1-3(1)$ & - & - \\
\hline 1 & $1-3(2)$ & nc & $3-9(6)$ & $2-8(3)$ & 1 & 1 & 1 & 1 & - & $2-3(3)$ & 1 \\
\hline 2 & 2 & $3-7(5)$ & $4-9(7)$ & $3-5(3)$ & $1-3(1)$ & 1 & 1 & $1-2(1)$ & - & - & $1-2(1)$ \\
\hline 3 & $1-3(2)$ & 1 & 1 & $1-2(1)$ & $2-5(3)$ & $1-3(2)$ & $1-5(1)$ & $1-3(3)$ & - & - & - \\
\hline 4 & $2-3(3)$ & $2-7(5)$ & $2-7(4)$ & $2-6(3)$ & $1-4(2)$ & $2-3(2)$ & $1-3(1)$ & $1-2(1)$ & $1-4(3)$ & - & - \\
\hline 5 & $1-3(2)$ & 1 & $2-4(3)$ & $2-10(7)$ & $3-5(5)$ & $1-3(1)$ & $1-2(1)$ & $1-2(1)$ & - & - & - \\
\hline 6 & $1-3(2)$ & 1 & $1-4(1)$ & $1-3(1)$ & 1 & 1 & 1 & 1 & - & - & - \\
\hline 7 & $1-3(2)$ & $2-5(3)$ & $2-4(3)$ & $1-4(2)$ & $1-4(3)$ & $1-3(2)$ & 1 & 1 & - & - & - \\
\hline 8 & 1 & - & - & $2-4(3)$ & $1-3(2)$ & $1-2(2)$ & $1-2(2)$ & $2-3(2)$ & - & - & - \\
\hline 9 & $2-4(2)$ & 1 & 1 & 1 & 1 & 1 & 1 & 1 & $1-2(1)$ & - & - \\
\hline 10 & 1 & - & - & $1-3(3)$ & 1 & 1 & $1-2(1)$ & $1-4(2)$ & - & - & - \\
\hline 11 & $2-4(3)$ & - & - & 1 & 1 & 1 & 1 & 1 & - & - & - \\
\hline 12 & $1-3(2)$ & - & - & - & - & - & $1-3(2)$ & - & - & - & - \\
\hline 13 & - & - & - & - & - & - & - & - & - & - & - \\
\hline 14 & - & - & - & 1 & 1 & 1 & $1-2(1)$ & $1-3(1)$ & 1 & - & - \\
\hline
\end{tabular}

$a$ : based on counts made on 9 - 20 setae of 20 individuals; nc: not counted. 


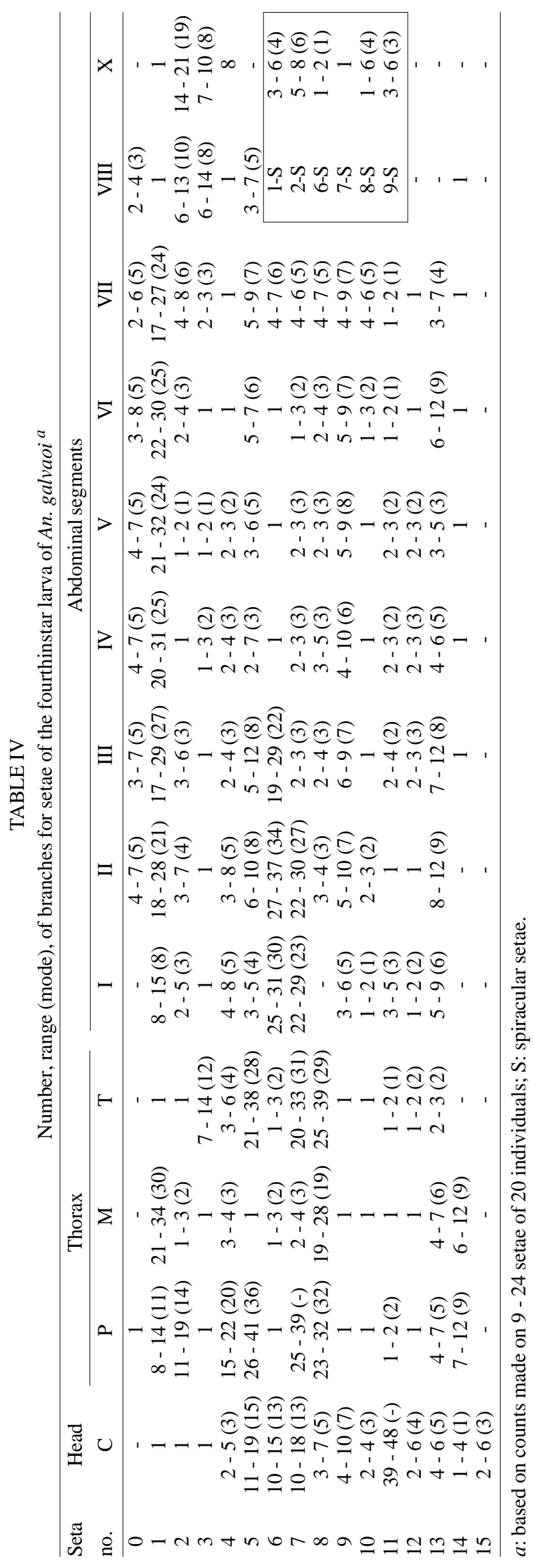

rized biological data from literature records for individuals identified as An. galvaoi.

Little is known about bionomics of An. galvaoi. Deane et al. (1946b) observed immatures of An. galvaoi in a puddle with grass and algae in full sun. Similarly, Lopes and Lozovei (1995) found immatures of An. galvaoi, which they did not separate from those of An. evansae and An. oswaldoi, in streamlet containing floating and emergent vegetation in full sun. The breeding site was in highly devastated anthropic environment. An. galvaoi was observed to be a zoophilic species, blood feeding on cattle and pigs but it was also attracted to humans (Tadei et al. 1998). This species was collected inside primary tropical forest in Balbina, State of Amazonas (Lourenço-deOliveira \& Luz 1996), in rural zone in Ariquemes, State of Rondônia (Tadei et al. 1998), in Itaipu hydroelectric reservoir area (Guimarães et al. 1997) and Taquaruçu dam area in the Paranapanema River basin (Tubaki et al. 1999) the latter two dams in Southern Brazil. In the Ribeira Valley area, State of São Paulo, An. galvaoi was collected in an open area and in peridomiciliary environment (Dutra et al. 1996). Females of An. galvaoi were also collected inside and outside houses, feeding on humans all night (from 6:00 pm to 6:00 am) in endemic area of malaria in the State of Maranhão, North of Brazil (Oliveira-Pereira \& Rebêlo 2000). It was also collected in Shannon trap, with activity peaks between 6:45 pm to 7:30 pm (Guimarães et al. 1997). Tubaki et al. (1999) found that An. galvaoi population activity peaked either in winter or early spring in Taquaruçu dam area, Southern Brazil. Also, generally An. galvaoi frequency in Shannon trap collections was higher before filling up the reservoir and then this taxon was replaced by An. albitarsis l.s. after the formation of the lake. Tadei et al. (1998) observed increase in An. galvaoi population density during dry season when An. darlingi decreased. Contrary, it was more frequent during rainy season in Pinheiro, State of Maranhão (Oliveira-Pereira \& Rebêlo 2000 ) but it was collected during dry and rainy seasons, however, more frequent in the latter in São Luis, State of Maranhão (Xavier \& Rebêlo 1999).

Material examined - PARATYPE: An. galvaoi, Rio Branco City, State of Acre, Brazil, Causey et al. coll., 1 male, 1 female reared from eggs, larval and pupal exuviae and male genitalia were not examined (IOC). OTHER MATERIAL: 1 female labeled as An. capanemai by Causey from the same locality of paratypes and designated lectotype of An. galvaoi by Belkin et al. (1971) (FSP-USP $\mathrm{n}^{\mathrm{O}} \mathrm{E}-2140$ ). One hundred ten specimens of An. galvaoi were examined, as follows. BRAZIL, State of São Paulo, Bocaina, Jacaré-Pepira River, Route 255, km 125, Santa Leonor Farm, Jacaré Pepira River (2205'00"'S 4826'33”W), ES Bergo coll., 3-VII-1995, progeny broods from females collected upon human bait, $29 \mathrm{Le}, 33 \mathrm{Pe}, 22$ males, 9 females and 5 male genitalia; Pariquera-Açu, Experimental Station, OP Forattini coll., 18-VIII-1992, Shannon trap, open area, 6 females; OP Forattini coll., 21-VII-1992, CDC light trap, 1 female; Cananéia, Galiléia Reserve, OP Forattini coll., 19-VIII 1992, Shannon trap, 1 female; State of Minas Gerais, Passos, Serviço de Febre Amarela coll., Causey det., 1952, 2 males, 2 male genitalia. 
Phylogenetic analysis - The congruence of the separate ITS2 and COII datasets was tested using the Incongruence Length Difference test of Farris et al. (1995), implemented as the "Partition Homogeneity Test" in PAUP version 4.0b8 PPC (Swofford 2001), with 1000 replicates and 10 random additional tree searches per replicate and with invariant sites excluded (Cunningham 1997). The results of this test indicate that congruence cannot be rejected for ITS2 and COII datasets $(\mathrm{P}=1.000000)$.

The COII alignment produced 594 positions of which 493 were constant, 101 were variable and 43 were parsimony informative. The ITS2 alignment generated 417 positions, of which 277 were constant, 140 were variable and 55 were parsimony informative. The average nucleotide composition for COII was $36 \% \mathrm{~A}, 38 \% \mathrm{~T}, 14 \% \mathrm{C}$, and $12 \% \mathrm{G}$. For ITS2 the average nucleotide composition was $25 \%$ A, 20\% T, 27\% C, and 28\% G. For ITS2, uncorrect (p) sequence distance ranged from 0.06165 between $A n$. strodei and An. rondoni (Neiva \& Pinto) to 0.20189 between An. aquasalis and An. benarrochi. For the COII mtDNA, uncorrect (p) sequence distance ranged from 0.02140 between An. strodei and An. rondoni to 0.09806 between An. nuneztovari and An. benarrochi.

Parsimony analysis of combined ITS2 (rDNA) and COII (mtDNA) generated a single most parsimonious tree (MPT) with parsimony informative $\mathrm{L}=195, \mathrm{CI}=0.692$, and $\mathrm{RI}=0.496$ (Fig. 4). Analysis using successive approximations character weighting identified the same tree that was found in the unweighted analysis. The identical trees recovered in the unweighted and successive approximations character weighting analyses define one major clade containing two clades: a clade consisting of ( $A n$. benarrochi + An. galvaoi), and a clade corresponding to $[(A n$. aquasalis $+(A n$. oswaldoi + An. nuneztovari $)]$. Bootstrap support for the major clade is strong (100\% bootstrap support value). In contrast, relationship between An. benarrochi and An. galvaoi is only weakly supported (59\% bootstrap value). Bootstrap support for the grouping (An. aquasalis $+(A n$. oswaldo $+A n$. nuneztovari) ) is moderate (79\%) and for (An. oswaldoi + An. nuneztovari) is weak (68\%) (Fig. 4).

The single unweighted MPT was evaluated in the program Modeltest 3.06 PPC (Posada \& Crandall 1998). The likelihood ratio test found the HKY $+\Gamma$ model to be significantly better fitting than the next less complex model $(\mathrm{P} \leq 0.000001)$, whereas the Akaike Information Criterion (AIC) found the GTR + I (Rodríguez et al. 1990; General Time Reversible with a proportion of sites Invariant) model to be the best fitting. The model HKY $+\Gamma$ was used to conduct likelihood analysis. As a result, likelihood analysis yielded a single tree with a log likelihood of - Ln likelihood $=2976.53740$. The single ML tree topology (Fig. 5) is similar to that of MPT (Fig. 4). However, a comparison of the ML and MP trees indicates that disagreement between optimal MP and ML trees is restricted to the sister group relationship between An. galvaoi and An. benarrochi in the MP tree (Fig. 4), in contrast to the basal position of An. benarrochi relative to An. galvaoi in the ML tree (Fig. 5). Also, An. galvaoi is recovered in basal position within the clade [An. aquasalis + (An. oswaldoi + An. nuneztovari)]. This basal placement of An. galvaoi

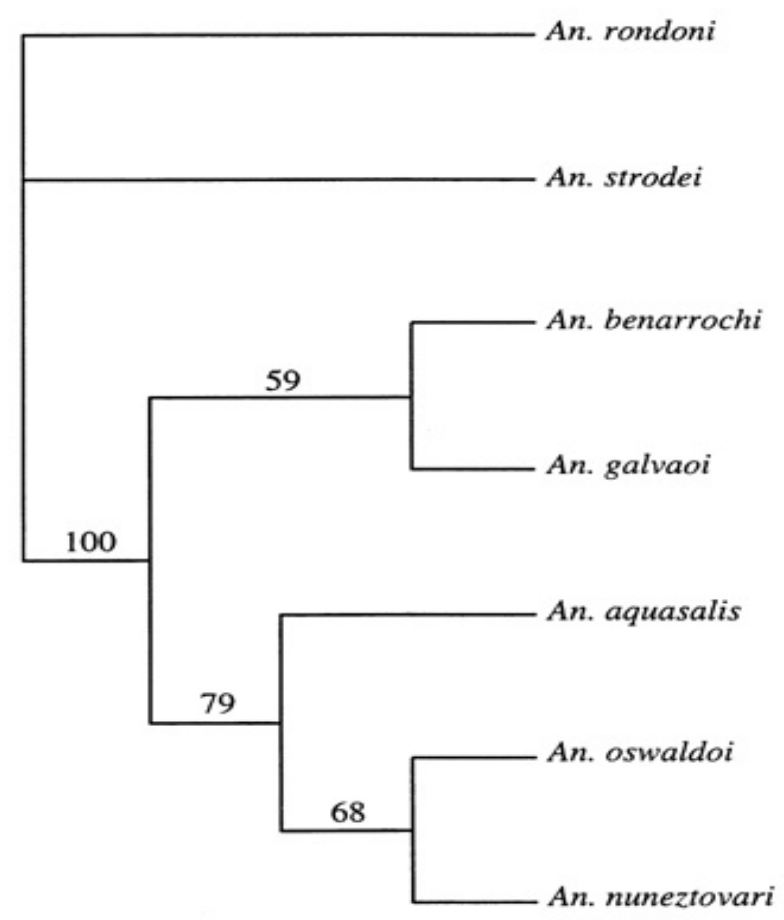

Fig. 4: the single tree identified by unweighted parsimony analysis of the combined rDNA (ITS2) and mtDNA (COII) data. Numbers above branches indicate parsimony bootstrap proportions. An: Anopheles.

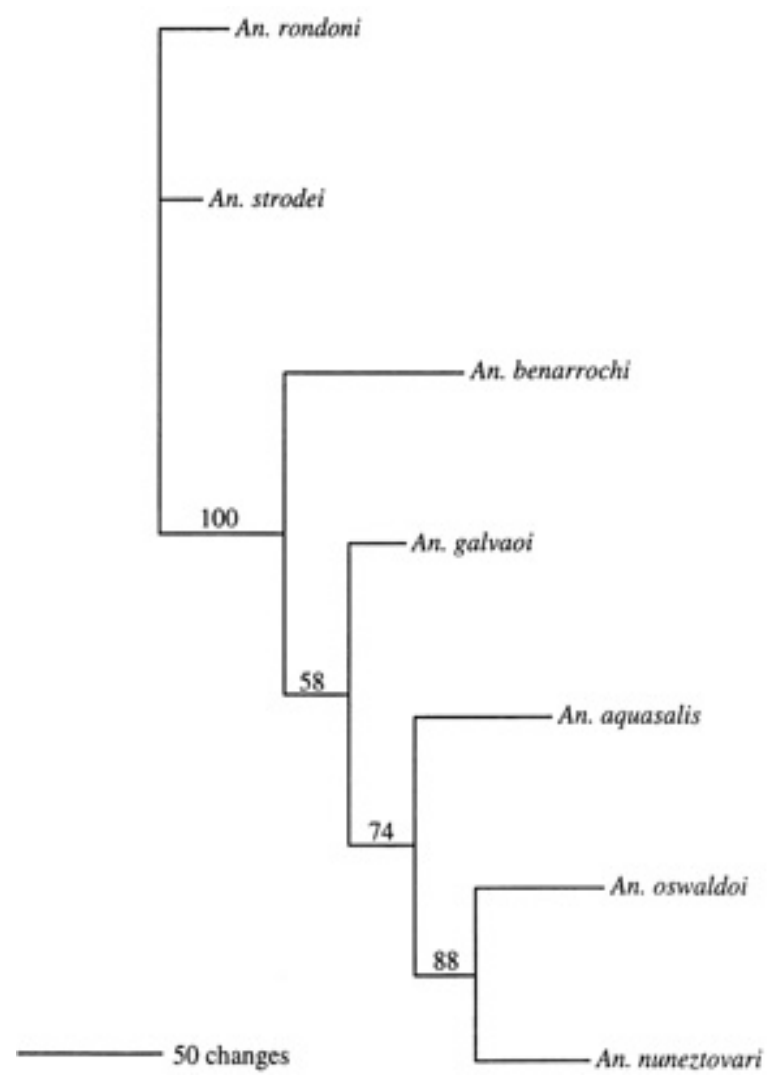

Fig. 5: the single tree identified by maximum likelihood analyses of the combined rDNA (ITS2) and mtDNA (COII) data under HKY + $\mathrm{G}$ model of nucleotide evolution. Numbers above branches indicate maximum likelihood bootstrap proportions. An: Anopheles. 
is only weakly supported (58\% bootstrap proportion). Similarly to MP topology, ML topology defines a strongly supported clade consisting of [An. benarrochi $+(A n$. galvaoi + An. aquasalis + An. oswaldoi + An. nuneztovari)] (100\% bootstrap proportion). The clade formed by $[($ An. aquasalis $+($ An. oswaldoi + An. nuneztovari $)]$ is moderately supported (74 \% bootstrap proportion), and the sister-group relationship between An. oswaldoi and An. nuneztovari is moderately supported ( $88 \%$ bootstrap proportion) (Fig. 5). Additionally, in all MP and ML analyses, An. rondoni is placed outside to the major clade leading to (An. benarrochi + An. galvaoi + An. aquasalis + An. oswaldoi + An. nuneztovari) as is An. strodei in unrooted trees.

\section{DISCUSSION}

As previously mentioned, Belkin et al. (1971) designated a female specimen (no. E-2140) deposited in the FSP-USP, as a lectotype of An. (Nys.) galvaoi. However, we are considering it, in the present study, as an invalid lectotype designation due to the following facts: (1) There is no evidence that such a specimen actually belonged to the type material. The specimen brings two labels: a) "R426, sp nova, Rio Branco" [handwritten in red ink]; b) newly typed, with accession number for FSP-USP collection. Attached to the glass vial, where the specimen is preserved, there is also a label with inscription "Anopheles capanemai". This name had never been published. In fact, this latter label was added when the material was deposited in the FSP-USP based on the register book of Faculdade de Medicina, Universidade de São Paulo (FMUSP): a) specimen female no. 694, An. (Nys.) capanemai Causey; b) Det. OR Causey; c) Rio Branco, Acre, Dr OR Causey, leg, Ad; d) 16-303; e) R426 (Causey). (2) Causey et al. (1943), when described An. (Nys.) galvaoi, declared that the "types", reared from eggs, would be deposited in the Universidade de São Paulo [Faculdade de Medicina, later, in 1969, transferred to FSP,], and the paratypes in the United States National Museum, Washington-DC, and in the Instituto Oswaldo Cruz, Rio de Janeiro. So, we are considering the "types" as holotype female and alotype male (according to the original description). Unfortunately, it was neither possible to find them in the USP collection nor the paratypes in the USNM. Therefore, the holotype is considered lost. Marchon-Silva et al. (1996) found two paratypes in the collection of the Instituto Oswaldo Cruz, Rio de Janeiro: 1 female, with 4 labels - "Anopheles (Nyssorhynchus) galvaoi Causey, Deane \& Deane", "Paratype", "paratipos criados de ovos postos por femea capturada em Rio Branco, Acre, Brasil" [paratypes reared from eggs laid by female captured in Rio Branco, Acre, Brazil], and "col. Inst O. Cruz no. 392". 1 male, with 5 labels - "Anopheles (Nyss.) galvaoi Causey, Deane \& Deane, paratype male", "criado de ovos postos por 1 femea de Rio Branco, Acre, Brasil", "col. Inst. O. Cruz no. 392, "lamina de gen.", and "Paratype".

Female of An. galvaoi is morphologically similar to that of An. benarrochi, An. aquasalis and An. strodei. The correct separation of females of these four species is not an easy task because except for An. aquasalis, the other three species are sympatric in most of their distribu- tion range. Sallum et al. (1997) found An. galvaoi, An. benarrochi, and An. strodei sympatric in the State of São Paulo, Southern Brazil. Separation of An. aquasalis from An. benarrochi is possible based on their distinct geographical distribution range, and also by a few characters suggested by Faran (1980). However, distinction of $A n$. galvaoi from An. benarrochi, An. aquasalis and An. strodei by morphological characters of adult female is more problematic. Tentatively, female of An. strodei can be separated from those of An. aquasalis, An. benarrochi and An. galvaoi based on the hindtarsal segment 2 which is dark-scaled in less than basal 0.40 in An. strodei but extends to more than basal 0.4 in An. benarrochi, An. galvaoi, and An. aquasalis. Wing pale and dark spot characters used to separate An. benarrochi from An. galvaoi and An. aquasalis, and An. galvaoi from An. aquasalis seem to be variable. For example, the wing pattern of dark and pale spots was demonstrated to vary depending on environmental conditions (Hribar 1995, 1997). The character scale color on vein M proposed by Gorham et al. (1967) to distinguish An. benarrochi from both An. galvaoi and An. aquasalis was observed to be variable. Specimens of An. benarrochi and An. galvaoi used for comparison in the current study were found to have vein $\mathrm{M}$ either mainly dark-scaled or pale-scaled. Distinction between An. galvaoi and An. aquasalis is not always possible by using the relative length of the dark basal spot and humeral pale spot, and subbasal pale spot and subbasal dark spot as proposed by Forattini (1962). Male of An. galvaoi can be easily distinguished from those of An. benarrochi, An.strodei and An. aquasalis by genitalic characters (see Faran 1980, for details). Distinction among pupal stages of An. galvaoi and the remaining members of the Albimanus Section (Faran 1980) seems to be problematic because it is mostly based on characters that are polymorphic. For example, using Faran's (1980) key, it is impossible to key out some specimens of An. galvaoi even in the first couplet because seta 9

length/segment VII length ranges from $0.21-0.37$ for this species. Consequently, specimens of An. galvaoi can be keyed out in both couplets. Pupal stage of An. galvaoi is very similar to those of An. benarrochi and $A n$. nuneztovari. Generally, pupa of An. galvaoi differs from that of An. benarrochi in having pinna moderately long, about 3.5 of meatus length, whereas in An. benarrochi it is 4.5 - 5.1 of meatus length. However, An. galvaoi seems to be indistinguishable from An. nuneztovari in the pupal stage. The presence of the pupal seta 12-VI was considered an anomaly for An. freeborni (Belkin 1953). Also, it is rarely present in members of Sabethini as either a short, reduced seta or only its alveolus (Harbach \& Knight 1980). In An. galvaoi, seta 12-VI, when present is short, reduced or moderately developed, 1-3-branched. It is interesting to note that the pupal seta $10-\mathrm{VI}$ is also present in $40 \%$ of the specimens examined for the present study. Similarly to seta $12-\mathrm{VI}$, seta $10-\mathrm{VI}$ is not commonly observed in pupal stage of species of the genus Anopheles. Fourthinstar larva of An. galvaoi is very similar to those of $A n$. benarrochi, An. aquasalis and An. evansae. However, An. galvaoi can be distinguished from An. benarrochi 
and An. aquasalis by having both setae 2-C and 3-C barbed. In An. benarrochi and An. aquasalis both 2-C and 3-C are plumose in about apical 0.5 , having moderately long to long branches. An. galvaoi can be separated from An. evansae based on few characters: (1) seta 1-X inserted outside saddle; (2) lateral arms of median spiracular plate, small but evident and distinct from the main plate; (3) seta 1-P with branches moderately broad, never narrow; and (4) seta 1-I with 8-15 long, broad leaflets. An. evansae: (1) seta 1-X inserted within saddle; (2) lateral arms of median spiracular plate minute; (3) seta 1-P with narrow, long leaflets; and (4) seta 1-I with 13-18 long, narrow leaflets.

Phylogenetic relationship - Faran (1980) divided the subgenus Nyssorhynchus into two sections: the Albimanus and Argyritarsis Sections based on morphological evidence, and the Albimanus Section was subdivided into two groups: the Albimanus and the Oswaldoi Groups, the former is monotypic and the latter includes 13 species. All species included in the current phylogenetic analysis belong to the Oswaldoi Subgroup of the Oswaldoi Group in the sense of Faran (1980). An. benarrochi, An. strodei and An. rondoni belong to the Strodei Complex, and An. galvaoi, An. aquasalis, An. oswaldoi and An. nuneztovari to the Oswaldoi Complex. The results of the current ML analysis place An. galvaoi within the clade composed by members of the Oswaldoi Complex, and An. benarrochi in the most basal position within a larger clade consisting of the Oswaldoi Complex plus An. benarrochi (Fig. 5). Contrary to Faran's (1980) hypothesis of phylogenetic relationships within the Oswaldoi Complex, An. galvaoi is placed as outgroup of the clade [(An. aquasalis + An. oswaldoi + An. nuneztovari)], and An. oswaldoi is sister to An. nuneztovari. According to Faran (1980), An. galvaoi is member of a clade, which includes An. aquasalis and An. oswaldoi, and An. nuneztovari belong to the clade (An. nuneztovari + An. trinkae Faran + An. rangeli). The results of all MP analyses found An. benarrochi sister to An. galvaoi, although with weak bootstrap support (59\%), and the clade consisting of these two taxa is the sister group of the clade (An. aquasalis + An. oswaldoi + An. nuneztovari) (Fig. 4). MP bootstrap support for the (An. benarrochi + An. galvaoi) and (An. galvaoi + An. aquasalis $+A n$. oswaldoi + An. nuneztovari) clades is strong $(100 \%)$. Finally, in both ML and MP topologies, relationship between An. galvaoi and An. benarrochi is ambiguous. In contrast, results of ML and MP bootstrap analyses strongly support monophyly of the clade corresponding to members of the Oswaldoi Complex $+A n$. benarrochi (100\% bootstrap proportion) (Figs 4, 5).

\section{ACKNOWLEDGMENTS}

To Dr Albino Morimasa Sakakibara, Departamento de Zoologia, Universidade Federal do Paraná for his valuable suggestions about nomenclature and providing helpful comments to improve the present work.

\section{REFERENCES}

Belkin JN 1953. Corrected interpretations of some elements of the mosquito larva and pupa (Diptera, Culicidae). Proc Entomol Soc Wash 55: 318-324.
Belkin JN, Schick RX, Galindo P, Aitken THG 1965. Mosquito studies (Diptera: Culicidae). XXV. Mosquitoes originally described from Brazil. Contrib Amer Entomol Inst 7: $1-64$.

Carpenter JM 1988. Choosing among equally parsimonious cladograms. Cladistics 4: 291-296.

Causey OR, Deane LM, Deane MP 1943. Descrição de um novo anofelino da parte alta do Vale do Amazonas Anopheles (Nyssorhynchus) galvaoi n. sp. Rev Paulista Med 23: 293-296.

Causey OR, Deane LM, Deane MP 1946. Studies on Brazilian Anophelines from the Northeast and Amazon regions. II. An illustrated key by male genitalic characteristics for the identification of thirty-two species of Anophelini, with note on dissection technique (Diptera: Culicidae). Am J Hyg, Monographic series no. 18, Baltimore, Maryland.

Coher EI 1948 (1949). A study of the female genitalia of Culicidae; with reference to characters of generic value. Entomol Amer (NS) 28: 75-112.

Cunningham CW 1997. Can three incongruence tests predict when data should be combined? Mol Biol Evol 14: 733-740.

Deane LM, Causey OR, Deane MP 1946a. Studies on Brazilian Anophelines from the northeast and Amazon regions. I. An illustrated key by adult female characteristics for the identification of thirty-five species of Anophelini, with notes on the malaria vectors (Diptera: Culicidae). Amer J Hyg, Monographic series no. 18, Baltimore, Maryland.

Deane MP, Causey OR, Deane LM 1946b. Studies on Brazilian Anophelines from the northeast and Amazon regions. III. An illustrated key by larval characteristics for the identification of thirty-two species of Anophelini, with description of two larvae. Amer J Hyg, Monographic series no. 18, Baltimore, Maryland.

Dutra AP, Natal D, Tubaki RM., Barata JMS, Menezes RMT, Urbinatti PR, Costa AIP 1996. Mosquitos (Diptera: Culicidae) da Reserva Estadual de Pedro de Toledo (Juquitiba, SP, Brasil). Rev bras Ent 40: 375-378.

Faran ME 1980. Mosquito studies (Diptera: Culicidae). XXXIV. A revision of the Albimanus Section of the subgenus Nyssorhynchus of Anopheles. Contrib Am Entomol Inst (Ann Arbor) 15: 1-215.

Farris JS 1969. A successive approximations approach to character weighting. Syst Zool 18: 374-385.

Farris JS, Kallersjo M, Kluge AG, Bult C 1995. Constructing a significance test for incongruence. Syst Biol 44: 570-572.

Felsenstein J 1985. Confidence limits on phylogenies: an approach using the bootstrap. Evolution 39: 783-791.

Forattini OP 1962. Entomologia Médica. Parte Geral, Diptera, Anophelini, vol. 1, Edusp, São Paulo, 662 pp.

Gorham JR, Stojanovich CJ, Scott HG 1967. Clave Ilustrada para los Mosquitos Anofelinos de Sudamerica Oriental, National Communicable Disease Center, Atlanta, 62 pp.

Guimarães AE, Mello RP, Lopes CM, Alencar J, Gentile C 1997. Prevalência de anofelinos (Diptera: Culicidae) no crepúsculo vespertino em área da usina hidrelétrica de Itaipu, no município de Guaíra, Estado do Paraná, Brasil. Mem Inst Oswaldo Cruz 92: 745-754.

Harbach RE, Knight KL 1980. Taxonomists' Glossary of Mosquito Anatomy, Plexus Publishing, Marlton, New Jersey, $415 \mathrm{pp}$.

Hasegawa M, Kishino H, Yano T. 1985. Dating the human-ape split by a molecular clock of mitochondrial DNA. J Mol Evol 22: 160-174.

Hribar L 1995. Costal wing spot variation within and among progeny of single female Anopheles nuneztovari (Diptera: Culicidae). Mosq Syst 27: 1-15.

Hribar L 1997. Effect of larval rearing temperatures on adult 
female morphology of Anopheles (Nyssorhynchus) albimanus (Diptera: Culicidae). Inver Reprod Develop 32: 85-88.

Lopes J, Lozovei AL 1995. Ecologia de mosquitos (Diptera: Culicidae) em criadouros naturais e artificiais de área rural do norte do Estado do Paraná, Brasil. I - Coletas ao longo do leito de ribeirão. Rev Saúde Públ 29: 183-191.

Lounibos LP, Duzak D, Linley JR 1997. Comparative egg morphology of six species of the Albimanus Section of Anopheles (Nyssorhynchus) (Diptera: Culicidae). J Med Entomol 34: 136-155.

Lourenço-de-Oliveira R, Luz SLB 1996. Simian malaria at two sites in Brazilian Amazon - II. Vertical distribution and frequency of Anopheline species inside and outside the forest. Mem Inst Oswaldo Cruz 97: 687-694.

Maddison DR, Maddison WP 2000. MacClade 4. Analysis of Phylogeny and Character Evolution, Sinauer Associates, Sunderland, Massachusetts.

Marchon-Silva V, Lourenço-de-Oliveira R, Almeida MD, SilvaVasconcelos A, Costa J 1996. The type specimens of mosquitoes (Diptera: Culicidae) deposited in the Entomological Collection of the Instituto Oswaldo Cruz, Rio de Janeiro, Brazil. Mem Inst Oswaldo Cruz 97: 471-478.

Oliveira-Pereira YN, Rebêlo JMM 2000. Espécies de Anopheles no município de Pinheiro (Maranhão), área endêmica de malária. Rev Soc Bras Med Trop 33: 443-450.

Posada D, Crandall KA 1998. Modeltest: testing the model of DNA substitution. Bioinformatics 14: 817-818.

Rodríguez F, Oliver JL, Marin A, Madina JR 1990. The general stochastic model of nucleotide substitution. $J$ Theor Biol 142: 485-501.

Sallum MAM, Bergo ES, Forattini OP 1997. First record of Anopheles benarrochi Gabaldon, Cova Garcia \& Lopez from the State of São Paulo, Southern Brazil. Mem Inst Oswaldo Cruz 92: 233-234.
Sallum MAM, Bergo ES, Forattini OP, Flores DC 2002a. The eggs of Anopheles galvaoi and An. evansae, two species of the subgenus Nyssorhynchus (Diptera: Culicidae). J Amer Mosq Control Assoc 18: 10-25.

Sallum MAM, Schultz TR, Foster PG, Aronstein K, Wirtz RA, Wilkerson RC 2002b. Phylogeny of Anophelinae (Diptera: Culicidae) based on nuclear ribosomal and mitochondrial DNA sequences. Syst Entomol 27: 361-382.

Sallum MAM, Schultz TR, Wilkerson RC 2000. Phylogeny of Anophelinae based on morphological characters. Ann Entomol Soc Amer 93: 745-775.

Swofford DL 2001. PAUP*. Phylogenetic Analysis Using Parsimony (*and Other Methods), Version 4. Sinauer Associates, Sunderland, Massachusetts.

Swofford DL, Olsen GJ, Wadell PJ, Hillis DM 1996. Phylogenetic inference. In DM Hillis, C Moritz, BK Mable (eds), Molecular Systematics, 2nd ed., Sinauer Associates, Sunderland, Massachusetts, p. 407-514.

Tadei WP, Thatcher BD, Santos JMM, Scarpassa VM, Rodrigues IB, Rafael MS 1998. Ecologic observations on Anophelinae vectors of malaria in the Brazilian Amazon. Am J Trop Med Hyg 59: 325-335.

Thompson JD, Gibson TJ, Plewniak F, Jeanmougin F, Higgins DG 1997. The ClustalX windows interface: flexible strategies for multiple sequence alignment aided by quality analysis tools. Nucleic Acids Res 24: 4876-4882.

Tubaki RM, Hashimoto S, Domingos MF, Berenstein S 1999. Abundance and frequency of culicids, emphasizing anophelines (Diptera: Culicidae), at Taquaruçu dam in Paranapanema basin, Southern Brazil. Rev bras Ent 43: 173184.

Xavier MMSP, Rebêlo JMM 1999. Espécies de Anopheles (Culicidae, Anophelinae) em área endêmica de malária, Maranhão, Brasil. Rev Saúde Pública 33: 535-541. 